\title{
Observations on a
}

\section{GLAUCOUS GULL at Calgary, Alberta}

\author{
by D. VAUGHN WESELOH* and \\ R. A. OWENS**
}

California and Ring-billed gulls nest at several locations near Calgary, Alberta. After their arrival in the early spring but before nesting activities are fully established, these gulls, as well as other migrant gulls, roost communally on several different sloughs within and near the city limits of southeast Calgary. In the early spring they roost primarily on large ice-bound sloughs. Later, as break-up progresses, they move to a single, large, alkaline slough shallow enough to stand in. It was during observations of these two gull species at their early spring roosts that the senior author first, and then repeatedly, observed a Glaucous Gull.

The gull, an almost totally white second year bird was first observed on March 28, 1972, at 6:30 p.m. It was discovered at about 500 yards distance with a 20 - $40 \mathrm{X}$ binocular telescope sitting with a small group of adult California and Ring-billed gulls. At this time it was studied for approximately 15 minutes: the plumage was reminiscent of a Snowy Owl, the wings, back and head being white with slight brown mottling. It was much larger than either the California or Ring-billed gulls and, when sitting. was at least as large as several adult Herring Gulls which were also present.

At his point the junior author was notified. However, due to the great number of gulls present at the roost by this time $(3,600-4,000$ birds) and the gull's flighty nature as clusk rapidly approached, the Glaucous Gull could not be found again.

Two days later, March 30, a second

* Department of Biology, University of Calgary, Calgary, Alberta.

**No, 115, 163 West 5th St., North Vancouver, British Columbia year Glaucous Gull (presumably same individual, as are all subseque sightings) was again located duri routine observations at the roost $(1 \mathrm{~m}$ west and 2 miles south of Shepa Alberta). A more complete descriptic which included the following poin was taken: 1. no black or gray on win wing tips or mantle; 2 . bill, which $y$ black-tipped, and legs appeared flesh pinkish in colour: 3. tail all white; faint mottling on wings, back and he: 5. larger than adult Herring Gull wh both were standing. These points are general agreement with J. Dwigh description of a second year Glauce Gull.'

On this occasion the gull was again a distance of 500 - 600 yards but with the next hour flew to about 300 yar where all the above points of $t$ description were confirmed. It remain at this location until observations wo discontinued at $7: 30$ p.m. At 1 sighting, like the one two da previously, the gull was sitting on the with a small group of adult Californ Ring-billed and Herring gulls but a co siderable distance removed from main mass of roosting gulls.

The Glaucous Gull remained in Calgary area until at least April 12 a was seen on 10 different occasions by fewer than 14 different people duri that period. These sightings are su marized in Table 1.

Because this Glaucous Gull w carefully observed over a relatively tended period of time (16 days a more than $83 / 4$ observation hours) so many experienced observers, so general comments about its behavic might be in order. One was impress with its great periods of inactivity. On least one evening, the gull remaineds 
ng, head tucked under the wing, during he entire time it was observed (about 1 $/ 2$ hours). At other times great pains ad to be taken by various observers to fouse the gull so that its diagnostic atures could be seen. Also, during all criods of observation at the roost, the ull showed absolutely no individual inraction with any of the other gull pecies; however, it appeared to take art in the all communal activities sociated with the roosting gulls, i.e., it articipated equally in upflight displays, re-roosting assemblages and activities nd it appeared at the same roost for hore than 2 weeks.

Much to the surprise of the observers, he Glaucous Gull was found during iid-morning on the Bow River at a oint approximately 6 miles south of the hepard roost on April 5. It was also een at this location during midlorning on April 7 and 8. At these mes it appeared to be scavenging for fod on the ice flows and along the hore as it flew up and down the river. the fact that it was feeding along the iver (a natural food source) becomes hore interesting when it is realized that uring that period when this gull was in he Calgary area, nearly 40 hours of ull-oriented observations were made at he three Calgary Sanitary Land Fill ites (garbage dumps) and never once was this large gull observed. Contrary to this, in at least two other cases where Glaucous Gulls have been observed in southern Canada (Vancouver, B.C., 1971, R. Drent, pers. comm.; and Nelson B.C., 1972, W. Merilees, pers. comm. and personal observation) they are known to frequent dumps regularly. The significance, if any, of these contradictory observations is not known.

The normal wintering range of the Glaucous Gull extends south from the Arctic coast and islands along both Atlantic and Pacific coasts of Canada. It is scarce and irregular in most of the southern interior even in migration, though it appears regularly in small numbers on the upper St. Lawrence River and on the Great Lakes."

The weather during the period March 28 to April 12 was quite variable and included periods of extremes, i.e., unseasonably cold and snowy as well as warm and sunny. Two days prior to the first sighting of the Glaucous Gull, there was an extensive cold front with much northerly and northwesterly wind that brought 2-3 inches of snow to the Calgary area. It is not untenable that the gull was blown inland by this storm.

From records available to us, this appears to be the sixth record of a Glaucous Gull in Alberta (photographs

TABLE 1.

Sightings of a Glaucous Gull near Calgary, Alberta March 28 through April 12, 1972

$\begin{array}{llcl}\text { Pate } & \text { Location } & \text { Time } & \text { Observer }(s)^{*} \\ \text { March 28 } & \text { Shepard Roost } & 6: 30-6: 45 \text { p.m. } & \text { DVW } \\ \text { March 30 } & \text { Shepard Roost } & 6: 30-7: 30 \text { p.m. } & \text { DVW } \\ \text { April 2 } & \text { Shepard Roost } & 7: 15-7: 30 \text { p.m. } & \text { WH, WGM, RP, MP, DVW } \\ \text { April 3 } & \text { Shepard Roost } & 6: 10-7: 30 \text { p.m. } & \text { BL, VL, MO, RAO, CWE, WS, DVW } \\ \text { April 4 } & \text { Shepard Roost } & 6: 10-7: 30 \text { p.m. } & \text { CW, DVW } \\ \text { April 5** } & \text { Bow River } & 9: 45-10: 15 \text { a.m. } & \text { RP, VL, DVW } \\ \text { April 7** } & \text { Bow River } & 8: 50-9: 35 \text { a.m. } & \text { VL } \\ \text { April 8 } & \text { Bow River } & 12: 15-12: 30 \text { p.m. } & \text { GA, WB } \\ \text { April 10 } & \text { Shepard Roost } & 6: 10-7: 35 \text { p.m. } & \text { DVW } \\ \text { April 12 } & \text { Shepard Roost } & 6: 10-7: 10 \text { p.m. } & \text { DVW }\end{array}$

"DVW - D.V. Weseloh, WH - Willis Hall, WGM - W. Garry McKay, RP - Richard Palindat, MP - Michael Palindat, BL - Bill Lang, VL - Virginia Lang, MO - Majorie Owens, CWE - Cleve Wershler, WS - Wayne Smith, CW - Cliff Wallis, GA - Gerry Ansell, WB - Wendy Beirness.

** photographed. 
of this specimen have been accepted by and are on file with Prof. W. Ray Salt, Edmonton). The first specimen, an adult, was collected at Lacombe in 1915. A second specimen was caught in a coyote trap at Youngstown in 1940. Both of these specimens are held by the Alberta Provincial Museum." During the winters of 1960 and 1961, a Glaucous Gull was reported from Lake Saskatoon, where it apparently sat on the ice and fed on dead ducks (W. R. Salt, in litt.). From the files of the Calgary Field Naturalists' Society there is a record of a Glaucous Gull observed at Beaverhill Lake (40 miles ESE of Edmonton) by seven observers in May, 1966.

\section{SUGAR WATER FOR HUMMINGBIRDS}

\section{AT LANIGAN, SASKATCHEWAN}

\section{by MRS. WALTER GUNTHER*}

My husband and I have derived much pleasure from a mutual hobby. For years we have observed the habits of Rubythroated Hummingbirds.

In 1965 we first saw two at one time. We suspected that they had a nest in our trees as we saw them frequently that summer. In 1968, I began keeping records of each sighting. Their visits to our flower garden are as frequent as 5 to 15 minutes. They are extremely busy from 6 to 7 a.m., around noon to 1 p.m., and again from 6 to 7 or 8 p.m.

The earliest we have seen them is June 2 and the latest is September 27. We are sure that my husband discovered their nest, high up in a poplar tree. One year, on the first occasion that I saw the young ones, they and their mother were flying right near the tree where we think the nest is. They put on a spectacular aerial display. At times I could hear their faint chipping sounds. They

\footnotetext{
${ }^{*}$ Box 114, Lanigan, Saskatchewan
}

It is hoped that this account will er courage closer observation of all gu congregations so that the frequency an circumstances of future visits by rar species might be better documented.

'DWIGHT, J. 1925. The Gulls (Laridae) of th World: their plumages, moults, variations relationships and distribution. Bull. Am. Mu Nat. Hist. 52: 63-408.

"GODFREY, W. E. 1966. The Birds of Canadd National Museum of Canada, Bulletin No. 20 Queen's Printer, Ottawa 428 pp.

3SALT, W. R. and A. L. WILK. 1966. The Birds Alberta. 2nd (Revised) Edition. Dept. of Industr and Development, Edmonton, Alberta. $511 \mathrm{pp}$

became quite unafraid of us. The dat on which we see the immature ones usually August 12 or 13.

In 1970, I was thrilled when I suc ceeded in obtaining several coloure snapshots of them. I set up my old box type camera on the kitchen window sill which faces east. If a "hummer" came t, a certain lily or the feeder, I would sna the shutter and, hopefully, have a pic ture. One day the female sat on the fenc for 20 minutes or more, scratching he head, spreading out her white-tipped fan-shaped tail. Truly a wondrous sight

If you wish to attract hummingbirds plant deep-throated flowers. Nicotina $\mathrm{i}$ splendid, also columbines, delphiniums morning glories, lilies with curled bac petals and many others attract them. I $1970, ' 71$, and ' 72 , we had feeders con taining red sugar water. They quarre over it. Please be advised that a feede must be washed at regular intervals Once they become used to it, the depend on it.

Observing hummingbirds is fascinating and rewarding hobby. W have had countless hours of enjoymen and relaxation from it. 